\title{
Yellow passion fruit postharvest conservation and quality according to organic and mineral fertilizers
}

\author{
Anália Lúcia Vieira Pachecoํㅗㄹ Mateus Francisco Pagliarini², \\ Gilberto Bernardo de Freitas ${ }^{3}$, Gerival Vieira ${ }^{4}$
}

\begin{abstract}
Yellow passion fruit are highly perishable after harvest. Organic products may have better nutritional quality and better postharvest conservation due to the application of different cultural practices such as organic fertilization and non-use of synthetic pesticides. The objective of this study was to evaluate the effects of organic fertilization on the quality and postharvest conservation of yellow passion fruit. The orchard was installed in a completely randomized design with four replications and four plants on the same row per experimental unit. The treatments were three types of fertilization applied in the orchard: mineral (MIN) recommended for the crop; organic (ORG), equivalent to the recommended potassium fertilization for the crop and $2 \times$ ORG with twice the ORG dose. The organic fertilizer used was partially cured cattle manure. The mineral and organic fertilizers were applied superficially. During the harvest, the fruits were classified according to mass, type A (above $175 \mathrm{~g}$ ), B (between 125 and $175 \mathrm{~g}$ ) and C (below $125 \mathrm{~g}$ ). The experiment was developed in a completely randomized design, in a factorial scheme (fertilization $\mathrm{x}$ fruit mass classes), with six replications and 90 fruits per treatment. Fruits of plants fertilized with $2 \times$ ORG showed the same pulp yield (PY) of those that received MIN fertilization. Fruits of class $\mathrm{C}$ and fruits from plants fertilized with MIN showed greater weight loss. No difference between fertilization and mass classes was found for soluble solids (SS) and titratable acidity (TA). There was also no effect of fertilization on the SS / AT ratio, $\mathrm{pH}$ and vitamin $\mathrm{C}$ content, however, class B fruits showed, on average, higher values for these pulp aspects. The dose of ORG fertilizer was not enough to keep the fruit quality in relation to the PY, but the fruits from plants fertilized with ORG and $2 \times$ ORG kept up with better commercial quality for a longer period. The organic fertilizer with cattle manure is an efficient alternative to maintaining postharvest conservation of yellow passion fruit.
\end{abstract}

Index Terms: cattle manure; Passiflora edulis Sims f. flavicarpa Degener; vitamin C; weight loss.

\section{Conservação pós-colheita e qualidade dos frutos de maracujazeiro- amarelo de acordo com a adubação orgânica e mineral}

\begin{abstract}
Corresponding author: analia.pacheco@ufv.br
\end{abstract}

Received: Jamuary 10, 2017. Accepted: May 03, 2018.

Copyright: All the contents of this journal, except where otherwise noted, is licensed under a Creative Commons Attribution License.

\section{(cc) $\mathbf{E Y}$}

Resumo-Os frutos de maracujá-amarelo são altamente perecíveis após a colheita. Produtos orgânicos podem ter melhor qualidade nutricional e melhor conservação pós-colheita devido à aplicação de diferentes práticas culturais, como adubação orgânica e não utilização de pesticidas sintéticos. O objetivo deste trabalho foi avaliar os efeitos da adubação orgânica na qualidade e na conservação pós-colheita de frutos de maracujáamarelo. O pomar foi instalado em delineamento inteiramente casualizado, com quatro repetições e quatro plantas da mesma linha por unidade experimental. Os tratamentos foram três tipos de adubações aplicadas no pomar: mineral (MIN), recomendada para a cultura; orgânica (ORG), equivalente à adubação potássica, recomendada para a cultura e $2 \times$ ORG com o dobro da dose ORG. O adubo orgânico utilizado foi o esterco bovino parcialmente curtido. Os adubos mineral e orgânico foram aplicados superficialmente. Durante a colheita, os frutos foram classificados, de acordo com a massa, em tipo A (acima de $175 \mathrm{~g}$ ), B (entre $125 \mathrm{e}$ $175 \mathrm{~g}$ ) e C (abaixo de $125 \mathrm{~g}$ ). O experimento foi desenvolvido em delineamento inteiramente casualizado, em esquema fatorial (adubações x classes de massa dos frutos), com seis repetições e 90 frutos por tratamento. Frutos de plantas adubadas com $2 \times$ ORG apresentaram o mesmo rendimento de polpa (RDP) dos que receberam adubação MIN. Frutos da classe C e frutos de plantas adubadas com MIN apresentaram maior perda de massa. Não houve diferença entre as adubações e as classes de massa para o teor de sólidos solúveis (SS) e acidez titulável (AT). Também não houve efeito das adubações na relação SS/AT, pH e teor de vitamina $\mathrm{C}$; no entanto, frutos da classe B apresentaram, em média, maiores valores para esses aspectos da polpa. A dose de adubo orgânico equivalente à adubação ORG não foi suficiente para manter a qualidade dos frutos em relação ao RDP, porém os frutos provenientes de plantas adubadas com ORG e $2 \times$ ORG conservaramse com melhor qualidade comercial por maior período. A adubação orgânica, com esterco bovino, constitui eficiente alternativa para a manutenção da conservação pós-colheita dos frutos de maracujá-amarelo.

Termos para Indexação: esterco bovino; Passiflora edulis Sims f. flavicarpa Degener; vitamina C; perda de massa

\footnotetext{
'M.Sc., PhD in Fitotecnia, Federal University of Viçosa, Departamento de Fitotecnia, UFV, 3670-000 Viçosa, Minas Gerais, Brasil. Email: analia.pacheco@ufv.br ${ }^{2}$ M.Sc. in Fitotecnia, Federal University of Viçosa, Departamento de Fitotecnia, Viçosa, Minas Gerais, Brasil. Email: matpagliarini@gmail.com ${ }^{3}$ Professor D. Sc. of Federal University of Viçosa, Departamento de Fitotecnia, Viçosa, Minas Gerais, Brasil. Email: bernardo@ufv.br ${ }^{4}$ Professor D. Sc. of Federal University of Viçosa, Departamento de Fitotecnia, Viçosa, Minas Gerais, Brasil. Email: gerival@ufv.br
} 


\section{Introduction}

Fertilization mineral or organic can interfere in production and in internal and external characteristics of the fruit, and these effects vary according to the evaluated species, quantities and types of fertilizers used (DIAS et al., 2017; MARTUSCELLI et al., 2016; HEWIDY et al., 2015). Passion fruit is a demanding species in nutrients, but in a recent review on mineral nutrition and fruit quality, Aular et al. (2014) highlighted the lack of information on the effects of fertilization on this fruit, especially under tropical conditions.

After harvest passion fruits becomes a highly perishable, which predisposes it to rapid dehydration of the pericarp followed by wilting, thus reducing its conservation and trade period (POCASANGRE ENAMORADO et al., 1995; DURIGAN et al., 2004). The loss of quality and consequently, the commercial value occurs due to an intense respiratory activity and significant water loss, which leads to occurrence of alterations in the appearance of the fruit (CASTRO, 1994; SCHEER, 1994). The desirable characteristics depend on the needs of each commercial segment. For the juice industry, the varieties must present good pulp yield, high acidity, juice color of golden yellow and high content of soluble solids. For the market of fresh fruit, large and oval fruits are preferred by consumers (BRUCKNER et al., 2002).

The postharvest quality of fruits produced in organic farming system has been compared to those fruits from convention farming. The postharvest fruit quality of sweet passion fruit was influenced by organic fertilization, with greater accumulation of sugars in the fruits that received the highest dose of pig manure (DAMATTO JUNIOR et al., 2005). Lettuce grown in organic farming presented longer post-harvest preservation, with higher values of soluble solids and higher titratable acidity at the end of storage, compared to those conventionally produced (REIS et al., 2014). However, when oranges fruits from organic and conventional orchards were compared for five years, no differences in the qualitative characteristics were found, except for total soluble solids and vitamin C content, which were higher in fruits of the conventional orchard (PETRY et al., 2012). Strawberries produced under organic production system exhibited higher soluble solids contents and firmer pulp than those produced under conventional system. Weight loss, titratable acidity and ascorbic acid concentrations were not influenced by farming systems. Each production system was responsible for benefit different attributes (ANDRADE et al., 2017).

Thus, the objective of this study was to evaluate the effects of organic fertilization on quality and postharvest preservation of yellow passion fruits.

\section{Material and methods}

The experiment was conducted in an orchard on Sementeira Experimental Farm which belongs to the Federal University of Viçosa, in the municipality of Visconde do Rio Branco, region of Minas Gerais Forest Zone, with an average altitude of $360 \mathrm{~m}, 21^{\circ} 47^{\prime} \mathrm{S}$ of latitude and $42^{\circ} 50^{\prime} \mathrm{W}$ longitute. According to Köppen classification, the climate is Aw (rainy tropical savanna) with average annual temperature of $21^{\circ} \mathrm{C}$, average rainfall of $1,270 \mathrm{~mm}$ and air relative humidity of $80 \%$. The area was occupied by natural pastures and in 2003, Mucuna cinereum was grown. No organic neither chemical fertilizer was applied before the orchard establishment. The two orchards were located nearby, in order to exclude possible pedoclimatic influences on the measured variables.

The soil in the area was classified as Red-Yellow Latosol, whose analyses displayed the following chemical characteristics at the $0-0,2 \mathrm{~m}$ and $0,2-0,4 \mathrm{~m}$ layers, respectively: $\mathrm{pH}\left(\mathrm{H}_{2} \mathrm{O}\right)=6.17$ and $6.23 ; \mathrm{P}=4.73$ and 2.97 $\mathrm{mg} \mathrm{dm}{ }^{-3} ; \mathrm{K}=14.58$ and $5.25 \mathrm{mg} \mathrm{dm}^{-3} ; \mathrm{Ca}^{+2}=4.63$ and 3.97 $\mathrm{cmol}_{\mathrm{c}} \mathrm{dm}^{-3} ; \mathrm{Mg}^{+2}=1.60$ and $1.60 \mathrm{cmol}_{\mathrm{c}} \mathrm{dm}^{-3} ; \mathrm{Al}^{3+}=0.00$ and $0.00 \mathrm{cmol}_{\mathrm{c}} \mathrm{dm}^{-3} ; \mathrm{H}+\mathrm{Al}=3.08$ and $2.09 \mathrm{cmol}_{\mathrm{c}} \mathrm{dm}^{-3}$; $\mathrm{SB}=6.32$ and $5.62 \mathrm{cmol}_{\mathrm{c}} \mathrm{dm}^{-3} ; \mathrm{CEC}(\mathrm{t})=6.32$ and 5.62 $\operatorname{coml}_{c} \mathrm{dm}^{-3}$; CEC (T)=9.40 and $7.71 \mathrm{cmol}_{\mathrm{c}} \mathrm{dm}^{-3} ; \mathrm{V}(\%)=$ 67 and 73 .

The seedlings were grown from seeds removed from fruits with commercial characteristics (thin skin, high-yield pulp and orange color pulp), collected from vigorous and productive plants, grown in the same experimental station where the experiment was conducted. The transplanting of seedlings in the field was held when they were 15 to $20 \mathrm{~cm}$ at height. The spacing was $3.5 \mathrm{~m}$ between rows and $4.0 \mathrm{~m}$ between plants with 714 plants ha${ }^{1}$. The holes ( $50 \mathrm{~cm}$ diameter and $50 \mathrm{~cm}$ deep) were opened with mechanical auger and each received in its preparation 10 liters of cattle manure, $500 \mathrm{~g}$ of thermophosphate and $200 \mathrm{~g}$ of dolomitic limestone. Lime was distributed on the walls and bottom and thermophosphate and cattle manure were mixed with soil from the opening of the hole. After filling, the hole remained in "rest" for about 30 days when the seedlings were transplanted. The seedlings were watered weekly during the dry season to allow their growth and establishment in the field.

The crop was grown in vertical training on barbless wire, stuck and stretched by fence posts spaced at $4 \mathrm{~m}$ with $1.80 \mathrm{~m}$ in height. The plants were kept in a single rod, eliminating the side shoots, up to exceeding $20 \mathrm{~cm}$ above the training wire. Two opposing shoots closer to the wire were selected and conducted to each side of the plant. Prunings were performed after the growth of the tertiary branches to keep the end of the branches at 40 $\mathrm{cm}$ from the ground. Diseases and pests were monitored and controlled when necessary, with products allowed in 
organic production systems, according to the normative instruction number 46 (BRASIL, 2011). During the period of the experiment, was made four sprays of DIPEL to control caterpillars and six sprays of Bordeaux mixture $(0.5 \%)$ were used to control fungal diseases. Weeds were controlled when necessary with mechanical mowing in between rows and manual hoeing in the planting line.

The orchard was installed in a completely randomized design with four replications and four plants on the same row per experimental unit. The treatments were three types of fertilization applied superficially in the orchard: mineral, recommended for the crop, as control (MIN); organic, equivalent to potassium fertilization recommended for the crop (ORG); and twice as much as the cattle manure used in ORG treatment $(2 \times \mathrm{ORG})$. The organic fertilizer used was partially cured cattle manure. The organic fertilization was based on equivalence with the potassium fertilization because this nutrient is the most exported by fruit harvesting besides being recommended in larger quantities for passion fruit (BORGES et al., 2003). The amount of mineral and organic fertilizers (cattle manure) per plant were based on soil fertility, chemical composition of manure $\left(\mathrm{N}=1,85 \mathrm{dag} \mathrm{kg}^{-1} ; \mathrm{P}_{2} \mathrm{O}_{5}\right.$ $=1,72 \mathrm{dag} \mathrm{kg}^{-1} ; \mathrm{K}_{2} \mathrm{O}=2,08 \mathrm{dag} \mathrm{kg}^{-1}, \mathrm{Ca}=1,493 \mathrm{dag} \mathrm{kg}^{-1}$; $\mathrm{Mg}=0,882$ dag kg ${ }^{-1} ; \mathrm{S}=0,648 \mathrm{mg} \mathrm{kg}^{-1} ; \mathrm{Zn}=185 \mathrm{mg} \mathrm{kg}^{-1}$; $\mathrm{Fe}=13.630 \mathrm{mg} \mathrm{kg}^{-1}, \mathrm{Mn}=493,3 \mathrm{mg} \mathrm{kg}^{-1} ; \mathrm{Cu}=38,9 \mathrm{mg}$ $\mathrm{kg}^{-1}$ and $\left.\mathrm{B}=27,2 \mathrm{mg} \mathrm{kg}^{-1}\right)$ and expected yield (15-20 t ha $^{-1}$ ) according to Piza Júnior et al. (1996). Fertilization, mineral and organic, were split in four times during the rainy season with an interval of approximately two months between applications.

The amount of MIN applied per plant were, as follows: $140 \mathrm{~g}$ ammonium sulfate (AS), $105 \mathrm{~g}$ simple superphosphate (SS) and $105 \mathrm{~g}$ of potassium chloride (PC). The ORG and $2 \times$ ORG treatments were, as follows: 12 and $24 \mathrm{~L}$ per plant, respectively. Both were applied in September and December 2004, February and April 2005. The amount of nutrients $\left(\mathrm{g} \mathrm{plant}^{-1}\right)$ provided by fertilizations MIN, ORG and $2 \times$ ORG are in Table 1 .

Fruit were harvested when they presented about 30 to $40 \%$ of the skin surface yellow colored. The peduncles were kept attached to the fruits, which were packed in boxes after harvest and transported. In the laboratory, the fruits were sorted into homogeneous plots regarding the maturation stage (external appearance of the skin color) and the presence of minor defects (healed injury, superficial injury, stains, deformation and wrinkling). Then, within each plot, the fruits were classified into three weight classes $(\mathrm{A} \geq 175 \mathrm{~g}, \mathrm{~B}=125-175 \mathrm{~g}$ and $\mathrm{C} \leq 125 \mathrm{~g})$ and stored under natural atmospheric conditions, arranged on bench in the laboratory itself (Table 2).

The experiment was conducted in a completely randomized design with six replications, and 15 fruits per experimental unit, in a $3 \times 3$ factorial design, with three types of fertilizers applied in the orchard (MIN, ORG and $2 \times \mathrm{ORG})$, and three fruits classes $(\mathrm{A} \geq 175 \mathrm{~g}, \mathrm{~B}=$ $125 \mathrm{~g}-175 \mathrm{~g}$ and $\mathrm{C} \leq 125 \mathrm{~g})$. For interpretation of the data, analysis of variance, Tukey and Dunnet tests and regression analysis were performed, whose coefficients were tested by the $t$ test at $5 \%$ probability. In case of statistical significance, means were compared using the test of Dunnett (organic fertilizers compared to mineral) and test of Tukey (fruit classes) at 5\% probability.

At the end of the storage period, 15 fruits per experimental unit were weighed individually in semianalytical scale and then transversely sectioned for extraction of pulp with seed (PS). Subsequently, the skins were weighed separately, and the mass of the PS was obtained by difference. Samples of PS of each treatment were stored in high density polythene bags and stored at $-18^{\circ} \mathrm{C}$ for subsequent chemical analysis. The pulp yield (PY) was determined by the ratio between PS and fruit weight (FW) multiplied by 100 . The skin thickness (ST) was determined in the equatorial region of the fruit, by direct measurement with calipers at two points of each sectioned fruit.

To determine the weight loss (WL) during the storage period, the fruit were weighed every three days in semi-analytical scale, until reaching more than $8 \%$ of weight loss, which is a value above which the fruit loses commercial quality since it is considered wilted (CEAGESP, 2001). The mass difference between the evaluations was accumulated during the course of the experiment and the result of WL in relation to the initial mass expressed as a percentage.

Samples of PS were thawed and sieved through fine mesh to extract the seeds, and then juice was homogenized so analysis could be performed. The soluble solids content was determined using a reading table with refractometer within the range of 0 to $50^{\circ}$ Brix. The titratable acidity of the pulp was determined according to the methodology recommended by AOAC (1990), and the results were expressed in grams of citric acid per $100 \mathrm{ml}$ of pulp. The SS/TA ratio was obtained by dividing the soluble solids titratable acidity values. The $\mathrm{pH}$ of the pulp was determined by direct reading on previously calibrated digital $\mathrm{pHmeter}$. The vitamin $\mathrm{C}$ content was determined by the method of Tillmans according to the methodology described by AOAC (1990), and the results were expressed as milligrams of ascorbic acid per $100 \mathrm{ml}$ of pulp.

\section{Results and discussion}

Interaction between fertilization and classes of fruit was found only for the variable PY $(\mathrm{P}<0.05)$. Fruits of plants fertilized with $2 \times \mathrm{ORG}$, showed similar PY to those of MIN in all classes (Table 4). However, the C class fruits, from ORG fertilized plants presented lower PY than fruits of plants fertilized with MIN and $2 \times$ ORG. 
The increase in pulp yield of passion fruit was expected with the increase of $2 \times$ ORG fertilization dose, since the increase in the frequency of fertilization with cattle biofertilizer resulted in an increase in pulp yield (DIAS et al., 2011). In passion fruits treated with a dose of 1.21 plant $^{-1}$ of cattle biofertilizer were found pulp yield around 50\% (CAVALCANTE et al., 2012). However, the authors point out that in the literature, there is no standard value considered ideal for the percentage of yellow passion fruit pulp. In this study, the maximum found was of $63.60 \%$ for $\mathrm{C}$ class fruits, which received $2 \times \mathrm{ORG}$ fertilization. However, it is important to mention that the assessment regarding the PY of the fruits was performed after nine days of storage when these fruits displayed $8 \%$ of WL at least. In passion fruits, the increase in juice yield in percentage is due to the higher dehydration of the skin in relation to the pulp (SILVA et al.,1999).

The lower PY in C class fruits from ORG fertilized plants may be related to nutrition of plants, as the nutrients present in the cattle manure are released more slowly than mineral fertilizers (SILVA et al., 2014). For plants fertilized with $2 \times \mathrm{ORG}$, the PY might have been found due to the high nutrient supply to the growing area. In this case, despite of the slow mineralization and release of nutrients, the larger amount of the added manure provided greater availability of nutrients. Sweet passion fruits fertilized with a dose of cattle manure of $40 \mathrm{~g} \mathrm{~N}_{\text {plant }}{ }^{-1}$ also showed lower pulp yield when compared to the fruits that received mineral fertilizer and organic fertilizer with $120 \mathrm{~g} \mathrm{~N} \mathrm{plant}^{-1}$ (DAMATTO JUNIOR et al., 2005).

The ST was not affected by treatments $(\mathrm{P}>0.05)$. The lack of artificial pollination may also influence the thickness of the fruit skin (KRAUSE et al., 2012; MARTINS et al., 2014). The application of cattle biofertilizer influenced the thickness of passion fruit skin and as the doses were increased, the skin became thinner (CAVALCANTE et al., 2012). In this study, the average value was $6.99 \mathrm{~mm}$. Hybrids of yellow passion fruit also grown without artificial pollination and without irrigation, found the largest thickness in the skin with 7.6 mm (ZACCHEO et al., 2012).

From the sixth day of storage, fruits from plants fertilized with MIN presented higher WL than fruit plants fertilized with cattle manure in both doses used (Table 3). Fruits obtained from plants fertilized with ORG and $2 \times$ ORG presented WL higher than $8 \%$ only at nine days of storage, which means that they maintained better commercial quality for a longer period of time, which would facilitate the trade of the fruit. At $8 \% \mathrm{WL}$, the fruits were already wilted and lost commercial value (CEAGESP, 2001). In other studies, the postharvest conservation of fruits or vegetables is usually evaluated under a modified atmosphere or with a storage temperature reduction (SOUZA et al., 2017; STANGER et al., 2017). However, in this study, the postharvest conservation of yellow passion fruit fruits was evaluated under natural atmospheric conditions, simulating the way these fruits are marketed.

The $\mathrm{C}$ class fruits had more than $10 \% \mathrm{WL}$ at six days of storage, while fruits of A class at nine days of storage had less than $7 \%$, with still good commercial value. Class B fruits presented intermediate values of WL, however at nine days of storage, they already had more than $8 \%$ (Table 5). The smaller the fruit, the higher the weight loss during storage because the contact surface is higher with the atmospheric air (CHITARRA; CHITARRA, 2005). Thus, $\mathrm{C}$ class fruits should be commercialized as soon as possible to avoid losses related to the mass during storage.

These results for weight loss of fruits may be related to the calcium supply by different fertilizations since it is an effective nutrient in preserving the cell wall structure, in particular, the region of the middle lamella (TAIZ; ZEIGER, 2017). The increase in the levels of calcium in pineapple fruits provided greater resistance in the cell wall, making it difficult the action of pectic enzymes, promoting greater integrity to the cells, resulting in increased shelf life of fruits (MARQUES et al., 2005). It can be seen that MIN fertilized fruits received less amount of calcium than those fertilized with ORG and $2 \times$ ORG (Table 1). Apples from organic farming with intensive use of organic fertilizers had higher firmness of pulp and skin, granting storage period $12 \%$ higher than those produced in the conventional system (WEIBEL et al., 2000).

No difference and no interaction between fertilizations and weight classes were found for the content of SS and TA, which presented average values of

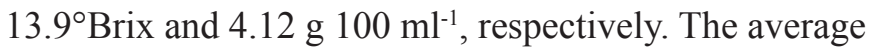
levels of SS and TA were lower than those found in some studies, but it is within that required by legislation. The minimum levels for passion fruit pulp, for SS and TA

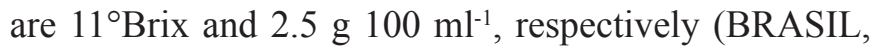
2000). For the industry and for the fresh fruit market as well, the SS content must be high. For the industry, for example, the higher the value of SS of the fruit, the lower the quantity of fruits used for the concentration of juice (NEGREIROS et al., 2008).

No effects of the fertilizations on the values for SS/ $\mathrm{TA}$ ratio, vitamin $\mathrm{C}$ content and $\mathrm{pH}$ were found. However, class $\mathrm{B}$ fruits showed, on average, higher values than fruits of class A and C (Table 6). The taste of the fruit is measured by the SS/TA ratio and due to the balance between acids and sugars (CHITARRA; CHITARRA, 2005). Considering the minimum values of SS and TA required by law, the SS/TA ratio should be at least 4.4. This experiment found values below this minimum because the TA content is higher than the minimum required by legislation (BRASIL, 2000). The levels of vitamin C found in this study are lower than those found by Dias et al. (2011), where the increase in the frequency of application of cattle biofertilizer increased levels of this vitamin, 
reaching up to $25.14 \mathrm{mg} .100 \mathrm{~mL}^{-1}$. Although effect of fertilizations on the content of vitamin $\mathrm{C}$ in the fruits was not found in this work.

In a total of 132 comparisons Worthington (2001) found that fruit and vegetables grown under organic farming system present, on average, $27 \%$ more vitamin $\mathrm{C}$ than under conventional farming. However, the content of vitamin $\mathrm{C}$ in fruits and vegetables may be influenced by several factors such as genotypic differences, climatic conditions, maturity stage, harvest and post-harvest management (LEE; KADER, 2000).
Values of $\mathrm{pH}$ of fruit pulp are in agreement with Damatto Júnior et al. (2005), who did not find any effects of organic fertilization on the $\mathrm{pH}$ of sweet passion fruits, which were also within values required by law, which is a minimum of 2.7 and maximum of 3.8 (BRASIL, 2000). Dias et al. (2011), when evaluating the effects of the application of cattle biofertilizers on the physical-chemical characteristics of yellow passion fruit, found values close to those found in this work, with $\mathrm{pH}$ reduction trend of fruit pulp.

Table 1. Number of macro and micronutrients $\left(\mathrm{g}_{\mathrm{glant}}{ }^{-1}\right)$ provided by fertilizations MIN (control), ORG, and $2 \times$ ORG .

\begin{tabular}{cccccccccccc}
\hline Fertilizations & $\mathrm{N}$ & $\mathrm{P}$ & $\mathrm{K}$ & $\mathrm{Ca}$ & $\mathrm{Mg}$ & $\mathrm{S}$ & $\mathrm{Zn}$ & $\mathrm{Fe}$ & $\mathrm{Mn}$ & $\mathrm{Cu}$ & $\mathrm{B}$ \\
\hline $\mathrm{MIN}$ & 112 & 76 & 252 & 85 & - & 186 & - & - & - & - & - \\
\hline ORG & 225 & 209 & 252 & 181 & 107 & 79 & 2.25 & 165.98 & 6.01 & 0.47 & 0.33 \\
$2 \times$ ORG & 450 & 418 & 504 & 362 & 214 & 158 & 4.50 & 331.96 & 12.02 & 0.94 & 0.66 \\
\hline
\end{tabular}

Table 2. Percentage of fruits in each mass class (A, B and C) at different fertilizations (MIN, ORG, $2 \times$ ORG).

\begin{tabular}{cccc}
\hline & \multicolumn{3}{c}{ Mass Classes } \\
\cline { 2 - 4 } Fertilization & $\mathrm{A}(>175 \mathrm{~g})$ & $\mathrm{B}(125-175 \mathrm{~g})$ & $\mathrm{C}(<125 \mathrm{~g})$ \\
\hline MIN & 16.08 & 32.41 & 48.33 \\
\hline ORG & 18.18 & 28.24 & 54.85 \\
$2 \times$ ORG & 13.73 & 33.49 & 54.67 \\
\hline Average & 16.00 & 31.38 & 52.62 \\
\hline
\end{tabular}

Table 3. Weight loss (WL) during the nine-day storage period, according to the three types of fertilization (MIN, ORG, $2 \times$ ORG).

\begin{tabular}{ccccccc}
\hline & \multicolumn{3}{c}{ WL } & & \\
\cline { 2 - 4 } Fertilization & 3 days & 6 days & 9 days & & Regression equation & $\mathrm{R}^{2}$ \\
\hline MIN & $4.12 \mathrm{a}$ & $9.13 \mathrm{a}$ & $11.04 \mathrm{a}$ & $\hat{\mathrm{Y}}=0.35+1.27 * \mathrm{D}$ & 0.95 \\
\hline ORG & $3.06 \mathrm{a}$ & $6.92 \mathrm{~b}$ & $8.22 \mathrm{~b}$ & & $\hat{\mathrm{Y}}=0.27+0.95 * \mathrm{D}$ & 0.97 \\
$2 \times$ ORG & $3.30 \mathrm{a}$ & $7.29 \mathrm{~b}$ & $8.60 \mathrm{~b}$ & & $\hat{\mathrm{Y}}=0.32+0.99 * \mathrm{D}$ & 0.96
\end{tabular}

${ }^{1}$ Means followed by the same letters of mineral fertilization (MIN), in the column do not differ from it by the test of Dunnett $(\mathrm{P}<0.05)$. $\mathrm{D}=$ days. * Significant by the $\mathrm{t}$ test $(\mathrm{P}<0.05)$.

Table 4. Pulp yield after nine days storage period according to the three fertilization types (MIN, ORG and $2 \times$ ORG) and three weight classes (A, B and C).

\begin{tabular}{cccc}
\hline \multirow{2}{*}{ Fertilizers } & \multicolumn{3}{c}{ Weight Classes } \\
\cline { 2 - 4 } & $\mathrm{A}$ & $\mathrm{B}$ & $\mathrm{C}$ \\
\hline MIN & $58.22 \mathrm{aA}$ & $58.68 \mathrm{aA}$ & $61.81 \mathrm{aA}$ \\
\hline ORG & $59.10 \mathrm{aA}$ & $60.53 \mathrm{aA}$ & $51.98 \mathrm{bB}$ \\
$2 \times$ ORG & $59.12 \mathrm{aA}$ & $61.48 \mathrm{aA}$ & $63.60 \mathrm{aA}$ \\
\hline
\end{tabular}

*Means followed by the same lowercase letter, in column, do not differ from MIN fertilization by the test of Dunnett ( $>>0.05)$. Means followed by the same upper-case letter, on the line, do not differ from each other by the test of Tukey $(\mathrm{P}>0.05)$. 
Table 5. Weight loss (WL) during the nine-day storage period in function of three weight classes (A, B and C).

\begin{tabular}{ccccccc}
\hline & \multicolumn{3}{c}{ WL } & & \\
\cline { 2 - 4 } Weight class & 3 days & 6 days & 9 days & & Regression equation & $\mathrm{R}^{2}$ \\
\cline { 5 - 7 } $\mathrm{A}$ & $2.66 \mathrm{~b}$ & $5.82 \mathrm{c}$ & $6.95 \mathrm{c}$ & & $\hat{\mathrm{Y}}=0.25+0.80 * \mathrm{D}$ & 0.98 \\
$\mathrm{~B}$ & $3.21 \mathrm{~b}$ & $7.36 \mathrm{~b}$ & $8.79 \mathrm{~b}$ & & $\hat{\mathrm{Y}}=0.26+1.02 * \mathrm{D}$ & 0.97 \\
$\mathrm{C}$ & $4.63 \mathrm{a}$ & $10.23 \mathrm{a}$ & $12.16 \mathrm{a}$ & $\hat{\mathrm{Y}}=0.43+1.40 * \mathrm{D}$ & 0.97 \\
\hline
\end{tabular}

${ }^{1}$ Means followed by the same letter in the column are not different by the test of Tukey $(\mathrm{P}>0.05)$. $\mathrm{D}=$ days. * Significant by the $\mathrm{t}$ test $(\mathrm{P}<0,05)$.

Table 6. Mean values of soluble solids/ titratable acidity (SS/TA), content of vitamin $\mathrm{C}$ and $\mathrm{pH}$ after a nine-day storage period according to the weight classes (A, B and C).

\begin{tabular}{cccc}
\hline & \multicolumn{3}{c}{ Weight Class } \\
\cline { 2 - 4 } Parameter & $\mathrm{A}$ & $\mathrm{B}$ & $\mathrm{C}$ \\
\hline SS/TA & $3.16 \mathrm{~B}$ & $3.67 \mathrm{~A}$ & $3.47 \mathrm{AB}$ \\
Vitamin C & $20.14 \mathrm{~B}$ & $23.97 \mathrm{~A}$ & $21.20 \mathrm{~B}$ \\
$\mathrm{pH}$ & $3.03 \mathrm{~B}$ & $3.11 \mathrm{~A}$ & $3.01 \mathrm{~B}$ \\
\hline
\end{tabular}

* Means followed by the same letter on the row do not differ from each other by the test of Tukey $(\mathrm{P}>0.05)$.

\section{Conclusion}

Organic fertilization with cattle manure at equivalent to potassium fertilization recommended for the crop (ORG) and twice as much as the cattle manure used in organic treatment $(2 \times \mathrm{ORG})$ is an effective alternative in the cultivation of passion fruit since it maintains postharvest conservation of the fruits, with less weight loss during storage, and with similar chemical characteristics to the fruits of plants grown with chemical fertilization.

\section{References}

ANDRADE, C.A.W.; MIGUEL, A.C.A.; SPRICIGO, P.C.; DIAS, C.T.S.; JACOMINO, A.P.Comparison of quality between organic and conventional strawberries from multiple farms. Revista Brasileira de Fruticultura, Jaboticabal, v.39, n.2, p.e-405), 2017.

AOAC - Association of Official Analytical Chemists. Official methods of analysis of AOAC International. $15^{\text {th }}$ ed. Washington, 1990. $2 \mathrm{v}$.

AULAR, J.; CASARES, M.; NATALE, W. Mineral nutrition and fruit quality of pineapple and passion fruit. Revista Brasileira de Fruticultura, Jaboticabal, v.36, n.4, p.1046-1054, 2014.

BORGES, A.N.; RODRIGUES, M.G.V.; LIMA, A.A.; ALMEIDA, I.A.; CALDAS, C.C. Nitrogen and Potassium effects on yield and quality of yellow passion fruit, under irrigation. Revista Brasileira de Fruticultura, Jaboticabal, v.25, n.2, p.259-262, 2003.
BRASIL. Ministério da Agricultura, Pecuária e Abastecimento. Instrução Normativa ${ }^{0} \mathbf{4 6}$ : regulamento técnico para os sistemas orgânicos de produção. Brasília (DF), 2011.

BRASIL. Ministério da Agricultura, Pecuária e Abastecimento. Instrução normativa $\mathbf{n}^{0} 001$ : regulamentos técnicos para fixação dos padrões de identidade e qualidade para polpas e sucos de frutas. Brasília (DF), 2000.

BRUCKNER, C.H.; MELETTI, L.M.M.; OTONI, W.C.; ZERBINI JÚNIOR, F.M. Maracujazeiro. In: BRUCKNER, C.H. (Ed.). Melhoramento de fruteiras tropicais. Viçosa: UFV, 2002. p.373-410.

CASTRO, J.V. Matéria-prima. In: TEIXEIRA, C.G.; CASTRO, J.V.; TOCCHINI, R.P.; NISIDA, A.L.A.C.; HASHIZUME, T.; MEDINA, J.C.; TURATTI, J.M.; LEITE, R.S.S.F.; BLISKA, F.M.M; GARCIA, A.E.B. Maracujá: cultura, matéria-prima, processamento e aspectos econômicos. 2.ed. Campinas: ITAL, 1994. p.143-160.

CAVALCANTE, I.H.; CAVALCANTE, L.F.; SANTOS, G.D. dos; BECKMANN-CAVALCANTE, M.Z.; SILVA, S.M. Impact of biofertilizers on mineral status and fruit quality of yellow passion fruit in Brazil. Communications in Soil Science and Plant Analysis, London, v.43, n.15, p.2027-2042, 2012. 
CEAGESP - Companhia de Entrepostos e Armazéns Gerais de São Paulo. Classificação do maracujá (Passiflora edulis Sims). São Paulo: Programa Brasileiro para a Melhoria dos Padrões Comerciais e de Embalagens do Maracujá-Azedo. 2001. Disponível em: <www. ceagesp.com.br>.

Chitarra, M. I. F.; CHITARrA, A. B. Pós-colheita de frutos e hortaliças: fisiologia e manuseio. 2. ed. rev.e ampl. Lavras: UFLA, 2005.

DAMATTO JUNIOR, E.R.; LEONEL, S.; PEDROSO, C.J. Adubação orgânica na produção e qualidade de frutos de maracujá-doce. Revista Brasileira de Fruticultura, Jaboticabal, v.27, n.1, p.188-190. 2005.

DIAS, D.G.; PEGORARO, R.F.; MAIA, V.M.; MEDEIROS, A.C. Production and postharvest quality of irrigated passion fruit after N-K fertilization.Revista Brasileira de Fruticultura, Jaboticabal, v.39, n.3, p.112, 2017.

DIAS, T.J.; CAVALCANTE, L.F.; FREIRE, J.L. de O.; NASCIMENTO, J.A. do; BECKMANN-CAVALCANTE, M.Z.; SANTOS, G.P.dos. Qualidade química de frutos do maracujazeiro-amarelo em solo com biofertilizante irrigado com águas salinas. Revista Brasileira de Engenharia Agrícola e Ambiental, Campina Grande, v.15, n.3, p.229-236, 2011.

DURIGAN, J.F.; SIGRIST, J.M.M.; ALVES, R.E.; FILGUEIRAS, H.A.C.; VIEIRA, G. Qualidade e tecnologia pós-colheita do maracujá. In: LIMA, A. de A.; CUNHA, M.A.P. (Org.). Maracujá: produção e qualidade na passicultura. Cruz das Almas: Embrapa Mandioca e Fruticultura, 2004. p.283-303.

HEWIDY, M.; TRAVERSA, A.; BEN-KHEDER, M.; CEGLIE, F.; COCOZZA, C. Short-Term Effects of Different Organic Amendments on Soil Properties and Organic Broccoli Growth and Yield. Compost Science \& Utilization, London, v.23, n.3, p.207-215, 2015.

KRAUSE, W.; NEVES, L.G.; VIANA, A.P.; ARAÚJO, C. A. T.; FALEIRO, F. G. Produtividade e qualidade de frutos de cultivares de maracujazeiro-amarelo com ou sem polinização artificial. Pesquisa Agropecuária Brasileira, Brasília, DF, v.47, n.12, p.1737-1742, 2012.

LEE, S.K.; KADER, A.A. Preharvest and postharvest factors influencing vitamin $\mathrm{C}$ content of horticultural crops. Postharvest Biology and Technology, Amsterdam, v.20, n.3, p.207-220, 2000.
MARQUES, A.C.; PINHEIRO, E.; VILAS BOAS, V.B.; LIMA, L.C. Influência do $\mathrm{CaCl}_{2}$ sobre a qualidade Póscolheita do abacaxi cv.Pérola. Ciência e Tecnologia de Alimentos, Campinas, v.25, n.1, p.32-36. 2005.

MARTINS, M.R.; REIS, M.C.; ARAÚJO, J.R.G.; LEMOS, R.N.S.; COELHO, A.O. Tipos de polinização e pastejo de abelhas Xylocopa spp.na frutificação e qualidade dos frutos de maracujazeiro. Revista Caatinga, Mossoró, v.27, n.1, p.187-193, 2014.

MARTUSCELLI, M.; DI MATTIA, C.; STAGNARI, F.; SPECA, S.; PISANTE, M.; MASTROCOLA, D. Influence of phosphorus management on melon (Cucumis melo L.) fruit quality. Journal of the Science of Food and Agriculture, New York, v.96, p.2715-2722, 2016.

NEGREIROS, J.R.S.; ARAÚJO NETO, S.E.; ÁLVARES, V.S.; LIMA, V.A.; OLIVEIRA, T.K. Caracterização de frutos de progênies de meios-irmãos de maracujazeiroamarelo em Rio Branco - Acre. Revista Brasileira de Fruticultura, Jaboticabal, v.30, n.2, p.431-437, 2008.

PETRY, H.B.; KOLLER, O.C.; BENDER, R.J.; SCHWARZ, S.F. Qualidade de laranjas 'Valência' produzidas sob sistemas de cultivo orgânico e convencional. Revista Brasileira de Fruticultura, Jaboticabal, v.34, n.1, p.167-174, 2012.

PIZAJÚNIOR, C.T.; QUAGGIO, J.A.; MELETTI, L.M.M; SILVA, J.R.; SÃO JOSÉ, A.R.; KARATI, R. Maracujá. In: RAIJ, B. van; CANTARELLA, H.; QUAGGIO, J.A.; FURLANI, A.M.C. (Ed.). Recomendações de adubação e calagem para o Estado de São Paulo. Campinas: IAC, 1996. p.148-149. (Boletim Técnico, 100).

POCASANGRE ENAMORADO, H.E.; FINGER, F.L.; BARROS, R.S.; PUSCHMANN, R. Development and ripening of yellow passion fruit. Journal of Horticultural Science, London, v.70, n.4, p.573-576, 1995.

REIS, H. F.; MELO, C. M.; MELO, E. P.; SILVA, R. A.; SCALON, S. P.Q. Conservação pós-colheita de alface crespa, de cultivo orgânico e convencional, sob atmosfera modificada. Horticultura Brasileira, Brasília, DF, v.32, n.3, p.303-309. 2014.

SCHEER, A. Reducing the water loss of horticultural and arable products during long term storage. Acta Horticulturae, The Hague, n.368, p.511-522, 1994.

SILVA, A.P.; VIEITES, R.L.; CEREDA, E. Conservação de maracujá-doce pelo uso de cera e choque a frio. Scientia Agrícola, Piracicaba, v.56, n.4, p.797-802. 1999. 
SILVA, V.B. da; SILVA, A.P.da; DIAS, B.O.; ARAUJO, J.L.; SANTOS, D.; FRANCO, R.P.Decomposition and mineralization of $\mathrm{N}, \mathrm{P}$ and $\mathrm{K}$ of cattle manure and poultry litter isolated or mixed. Revista Brasileira de Ciência do Solo, Viçosa, MG, v.38, n.5, p.1537-1546. 2014.

SOUZA, K.O. de; MOURA, C.F.H.; LOPES, M.M.A; RABELO, M.C.; MIRANDA, M.A.A. de. Quality of acerola (Malpighia emarginata) treated with gibberellic acid and stored under refrigeration. Revista Brasileira de Fruticultura, Jaboticabal, v.39, n.4:p.e-574, 2017.

STANGER, M.C.; STEFFENS, C.A.; AMARANTE, C.V.T. do; BRACKMANN, A.; ANESE, R.O. Quality preservation of 'Laetitia' plums in active modified atmosphere storage. Revista Brasileira de Fruticultura, Jaboticabal, v.39, n.2: (e-714), 2017.

TAIZ, L.; ZEIGER, E. Fisiologia vegetal. 6. ed. Porto Alegre: Artmed, 2017. 888 p.
WEIBEL, F.P.; BICKEL, R.; LEUTHOLD, S. Are organically grown apples tastier and healthier. A comparative field study using conventional and alternative methods to measure fruit quality. Acta horticulturae, The Hague, v.517, p.417-426. 2000.

WORTHINGTON, V.Nutritional quality of organic versus conventional fruits, vegetables, and grains. The Journal of Alternative and Complementary Medicine, New York, v.7, n.2, p.161-173, 2001.

ZACCHEO, P.V.C.; AGUIAR, R. S.; STENZEL, N.M. C.; SERA, T.; NEVES, C. S. V.J. Produção e características qualitativas dos frutos de híbridos de maracujazeiroamarelo. Revista Brasileira de Fruticultura, Jaboticabal, v.34, n.4, p.1113-1120. 2012. 